\title{
Evaluation of the Effects of Age Group, Gender and Seasonal Factors on Vitamin D Levels in 9496 Children
}

\section{Yaş Grubu, Cinsiyet ve Mevsimsel Faktörlerin D Vitamini Düzeylerine Etkisinin 9496 Çocukta Değerlendirilmesi}

\author{
Zafer Bagci ${ }^{1}$
}

\begin{abstract}
Öz
Amaç: Bu çalışmada, Orta Anadolu'daki bir eğitim ve araştırma hastanesi'nin çocuk kliniğinde bir yıl boyunca belirlenen D Vitamini düzeylerinin yaş gruplarına, cinsiyete ve mevsim özelliklerine göre değerlendirilmesi amaçlanmıştır.

Hastalar ve Yöntem: Bu retrospektif çalışma, bir hastanenin çocuk polikliniğine Ocak 2019-Aralık 2019 tarihleri arasında başvuran ve D vitamini düzeyi belirlenen 0-18 yaş arası çocukların verileri kullanılarak yapılmıştır. Çocuklar, Standart 6 önerilerine göre 28 gün-12 ay, 13 ay-2 yaş, 2-5 yaş, 6-11 yaş ve 1218 yaş olmak üzere beş farklı yaş grubuna ayrıldı. D vitamini düzeyleri yaş grubu, cinsiyet ve başvuru mevsimi açısından değerlendirildi.

Bulgular: Çalışmaya $5360(56.4 \%)$ 'i kız, 4136 (43.6\%)'sı erkek olmak üzere toplam 9496 çocuk dahil edildi. Katılımcıların 6472 (\%68.2)'sinin 25(OH)D düzeyi $20 \mathrm{ng} / \mathrm{mL}$ 'nin altında (eksikliği temsil eder), 2085 (\%21.9)'inin 21-29 $\mathrm{ng} / \mathrm{mL}$ arasında (yetersizliği temsil eder), 939 (\%9.9)'unun ise $30 \mathrm{ng} / \mathrm{mL}$ 'nin üzerinde (yeterliliği temsil eder) idi. Kızlarda D vitamini düzeylerinin erkeklere göre daha düşük olduğu, D vitamini düzeylerinin yaşla ters orantılı olduğu, D vitamini düzeylerinin en düşük değerlerine kışın, en yüksek değerlerine ise yazın ulaştığı belirlendi. Yaş grubu, cinsiyet ve başvuru mevsiminin $D$ vitamini düzeyleri üzerindeki etkileri istatistiksel olarak anlamlıydı $(P<0,001)$.

Sonuç: Tüm yaş grupları için ortalama $D$ vitamini düzeyleri ya yetersiz ya da eksikti. $0-18$ yas aras çocuklarda D vitamini seviyeleri yaş, cinsiyet ve mevsim ile ilişkilidir. Özellikle risk altındaki gruplarda D

Abstract

Aim: This study aimed to evaluate vitamin D levels, which were determined over a year in the pediatric clinic of a training and research hospital in Central Anatolia, according to age groups, gender, and seasonal characteristics.

Patients and Methods: This retrospective study was conducted using the data of children aged 0-18 years who applied to the children's clinic of a hospital between January 2019 and December 2019 and whose vitamin $\mathrm{D}$ levels were determined. Children were divided into five different age groups, 28 days -12 months, 13 months -2 years, 2-5 years, 6-11 years, and 12-18 years, in accordance with Standard 6 recommendations. Vitamin D levels were evaluated in terms of age group, gender, and admission season. Results: A total of 9496 children, $5360(56.4 \%)$ females and $4136(43.6 \%)$ males, were included in the study. A 25(OH)D level below $20 \mathrm{ng} / \mathrm{mL}$ (representing a deficiency) was found in $6472(68.2 \%)$ of the participants, while $2085(21.9 \%)$ participants had a $25(\mathrm{OH}) \mathrm{D}$ level between $21-29 \mathrm{ng} / \mathrm{mL}$ (representing an insufficiency) and $939(9.9 \%)$ participants had a $25(\mathrm{OH}) \mathrm{D}$ level over $30 \mathrm{ng} / \mathrm{mL}$ (representing sufficiency). It was determined that vitamin $D$ levels are lower in girls than in boys, vitamin $D$ levels are inversely proportional to age, and vitamin D levels reach their lowest values in winter and highest values in summer. The effects of age group, gender, and season of admission on vitamin D levels were statistically significant $(P<0.001)$.

Conclusion: The mean vitamin $D$ levels for all age groups were either insufficient or deficient. Vitamin $D$ levels in children aged 0-18 is related to age, gender, and season. Necessary measures should be taken, especially for at-risk groups, to prevent vitamin D deficiency or insufficiency.
\end{abstract}

University of Health Sciences, Konya Turkey

Address correspondence to: Zafer Bagci, vitamini eksikliğini veya yetersizliğini önlemek için gerekli önlemler alınmalıdır

University of Health Sciences, Konya City

Hospital, Department of Pediatrics, Konya, Anahtar Kelimeler: D vitamini düzeyleri, çocuk, yaş grubu, mevsim

Turkey.

e-mail: zfrbagci@gmail.com

Gelis Tarihi/Received: 11 August 2021 Kabul Tarihi/Accepted: 30 November 2021

Key words: Vitamin D levels, child, age group, season

Cite this article as: Bagci Z. Evaluation of the Effects of Age Group, Gender and Seasonal Factors on Vitamin D Levels in 9496 Children. Selcuk Med J 2021;37(4): $365-370$
Disclosure: Author has not a financial interest in any of the products, devices, or drugs mentioned in this article. The research was not sponsored by an outside organization. Author has agreed to allow full access to the primary data and to allow the journal to review the data if requested. 


\section{INTRODUCTION}

Vitamin $D$, a fat-soluble vitamin, is a steroid that is essential for a healthy life. Its main function is to ensure the growth and development of the skeletal structure by regulating the calcium and phosphorus metabolism. There are two major form of vitamin $D$. Ergocalciferol (vitamin D2) is found in plants and can be taken with food, and Cholecalciferol (vitamin D3) is an endogenously synthesized form (1). More than $90 \%$ of the vitamin $D$ in the human body is synthesized in the skin by the effect of sunlight. During exposure to sunlight, 7-dehydrocholesterol in the skin is converted to previtamin D3, which is thermally converted to vitamin D3. Vitamin D (D represents D2 or D3) hydroxylated first to $25(\mathrm{OH}) \mathrm{D}$ in the liver and then to $1,25(\mathrm{OH}) 2 \mathrm{D}$ in the kidneys. $25(\mathrm{OH}) \mathrm{D}$ is the main circulating form of vitamin $D$ and has a half-life of 2-3 weeks. It is the preferred indicator for measuring serum vitamin $D$ levels due to its long halflife. $1,25(\mathrm{OH}) 2 \mathrm{D}$ is the active form and its half-life is between 4-6 hours (2).

Sunlight is required for the endogenous production of vitamin D, though living indoors, the use of high factor skin protection, dark skin color, and seasonal and geographical conditions may reduce exposure to sunlight. In addition, vitamin $D$ deficiency or insufficiency may develop due to inadequate dietary intake or malabsorption (3). In children with a vitamin $D$ deficiency, the mineralization of bone tissue is impaired and rickets may develop. Vitamin $D$ deficiency or insufficiency is also a risk factor for many acute and chronic diseases (4). According to different prevalence studies, vitamin $D$ deficiency varies between $30 \%-80 \%$ worldwide (5). Although some regional studies conducted in Turkey have reported the prevalence of vitamin D deficiency/ insufficiency in children, there is no prevalence study covering the whole country yet. The aim of this study is to determine the prevalence of vitamin $D$ levels in children aged $0-18$ to reveal the distribution of vitamin $D$ levels by age group, gender, and seasons.

\section{PATIENTS AND METHODS}

Children between the ages of $0-18$ who applied to a training and research hospital pediatric clinic between January 01, 2019 and December 31, 2019 and whose serum 25-hydroxyvitamin $D$ levels were measured were included in this study. For this retrospective study, 01.07.2021 date and 01-25 number of the permission of the local ethic committee was obtained. Information about the patients was obtained from the electronic record archive of the hospital. Patients were grouped by age into five groups: 28 days -12 months (infancy), 13 months-2 years (toddler), 2-5 years (early childhood), 6-11 y (middle childhood), and 12-18y (early adolescence) in accordance with Standard 6 recommendations $(6,7)$. A 25(OH)D level lower than $20 \mathrm{ng} / \mathrm{mL}$ was defined as a "deficiency," with a level between $20-30 \mathrm{ng} / \mathrm{mL}$ being defined as an "insufficiency," and a level over $30 \mathrm{ng} / \mathrm{mL}$ being defined as a "sufficiency" $(8,9)$. 25(OH) D levels were determined using a chemiluminescent immunoassay (Siemens ADVIA Centaur XP, Siemens Healthcare Diagnostics, Erlangen, Germany).

Statistical Analysis: Statistical analysis was performed using the IBM SPSS Statistics program (Version 19.0 for Windows, NY: IBM Corp.). For the categorical variables, including age group, gender and season, descriptive statistics are presented as numbers and percentages. Numerical variables that are normally distributed are presented as means and standard deviations, and those that are not normally distributed are presented as medians, minima, and maxima. The normal distribution of vitamin $D$ levels was evaluated with the Kolmogorov-Smirnov test. The chi-square test was used to compare the categorical groups. Gender, age group, and admission season were determined as the main effects on vitamin $D$ levels. These factors and their interactions were evaluated with a univariate three-way analysis of variance. Sidak test adjustment was used for multiple comparisons. All statistical analyzes were performed formulating a two-way hypothesis with a $5 \%$ significance.

\section{RESULTS}

A total of 9496 children, 5360 (56.4\%) girls and 4136 $(43.6 \%)$ boys, were included in this study. Thirteen children with 25(OH)D3 levels between 100-150 ng/ $\mathrm{ml}$ (excess) and 16 children with intoxication above $150 \mathrm{ng} / \mathrm{mL}$ were not included in the study. A 25(OH)D level below $20 \mathrm{ng} / \mathrm{mL}$ (representing a deficiency) was found in 6472 (68.2\%) of the participants, while 2085 $(21.9 \%)$ participants had a $25(\mathrm{OH}) \mathrm{D}$ level between 21-29 $\mathrm{ng} / \mathrm{mL}$ (representing an insufficiency) and 939 (9.9\%) participants had a 25(OH)D level over $30 \mathrm{ng} / \mathrm{mL}$ (representing sufficiency). The distribution of the participants included in the study according to "gender," "age group," "application season," and "Vit D status" is given in Table 1.

When the age groups were evaluated in terms of gender, the difference was statistically significant $(P<$ 
Table 1. Distribution of patients by gender, age group, admission season and vitamin D status

\begin{tabular}{lll}
\hline & $\mathbf{n}$ & $\%$ \\
\hline Gender & & \\
Female & 5360 & 56.4 \\
Male & 4136 & 43.6 \\
Age Groups & & \\
$28 \mathrm{~d}-12 \mathrm{~m}$ & 525 & 5.5 \\
$13 \mathrm{~m}-2 \mathrm{y}$ & 957 & 10.1 \\
$2-5 \mathrm{y}$ & 2074 & 21.8 \\
$6-11 \mathrm{y}$ & 2640 & 27.8 \\
$12-18 \mathrm{y}$ & 3300 & 34.8 \\
Season & & \\
Winter & 2963 & 31.2 \\
Spring & 2054 & 21.6 \\
Summer & 2041 & 21.5 \\
Autumn & 2438 & 25.7 \\
Vit-D Status & & \\
Deficiency & & \\
Insufficiency & 6472 & 68.2 \\
Sufficiency & 2085 & 21.9 \\
\hline
\end{tabular}

0.001). The male gender was dominant under the age of 5 years, and the female gender was dominant over the age of 6 years $(P<0.001)$. When the participants were evaluated in terms of gender according to the seasons of application, no statistically significant difference was found $(P=0.327)$. The prevalence of vitamin $D$ deficiency was significantly higher in girls (3998 participants, 61.8\%) than boys, (2474 participants, $38.2 \%$ ) with $\mathrm{P}<0.001$. Comparison of age groups, admission seasons, and vitamin D statuses in terms of gender are given in Table 2.

According to the results of a univariate three-way analysis of variance, it was determined that the main effects of age group, gender, and application season on vitamin $D$ levels, as well as the interaction of these three factors, were statistically significant with $\mathrm{P}=$ 0.047 (Table 3 ). The seasonal variation of $25(\mathrm{OH})$ $D$ levels by age group and gender is presented in Figure 1. When vitamin $D$ levels were evaluated in terms of gender, the vitamin $D$ levels of boys were found to be higher than those of girls, yielding values of $19.4 \pm 10.3 \mathrm{ng} / \mathrm{mL}$ for boys and $15.8 \pm 10.1 \mathrm{ng} / \mathrm{mL}$ for girls, with $P<0.001$. The vitamin $D$ levels were highest in the infancy group and lowest in the early adolescence group, yielding values of $27.3 \pm 16.6 \mathrm{ng} /$ $\mathrm{mL}$ for the infancy group and $13.6 \pm 7.9 \mathrm{ng} / \mathrm{mL}$ for the early adolescence group, with $P<0.001$. According to the results of the multiple comparisons test, it was determined that values of vitamin $D$ levels across all age groups were statistically different $(P<0.001)$ as

Table 2. Comparison of age group, admission season and vitamin $D$ status in terms of gender

\begin{tabular}{lllll}
\hline & & Female $\mathbf{n ~ ( \% )}$ & Male $\mathbf{n ~ ( \% )}$ & $\mathbf{P}^{*}$ \\
\hline Age groups & $28 \mathrm{~d}-12 \mathrm{~m}$ & $241(45.9)$ & $284(54.1)$ & \\
& $13 \mathrm{~m}-2 \mathrm{y}$ & $460(48.1)$ & $497(51.9)$ & $<0.001$ \\
\multirow{2}{*}{ Season } & $2-5 \mathrm{y}$ & $1002(48.3)$ & $1072(51.7)$ & \\
& $6-11 \mathrm{y}$ & $1391(52.7)$ & $1249(47.3)$ & \\
& $12-18 \mathrm{y}$ & $2266(68.7)$ & $1034(31.3)$ & \\
Vitamin D Status & Winter & $1692(57.1)$ & $1271(42.9)$ & \\
& Spring & $1124(54.7$ & $930(45.3)$ & \\
& Summer & $1167(57.2)$ & $874(42.8)$ & $<0.327$ \\
\hline
\end{tabular}

${ }^{*}$ Chi-Square test

Table 3. Evaluation of the effects of gender, age group and season on vitamin D levels

\begin{tabular}{lllll}
\hline & df & F & $P^{*}$ & Partial Eta Squared \\
Gender & 1 & 37.052 & $<0.001$ & 0,004 \\
Age group & 4 & 304.352 & $<0.001$ & 0,114 \\
Season & 3 & 240.630 & $<0.001$ & 0,071 \\
Gender * Age group & 4 & 33.826 & $<0.001$ & 0.014 \\
Gender * Season & 3 & 2.412 & 0.065 & 0.001 \\
Age group * Season & 12 & 6.621 & $<0,001$ & 0.008 \\
Gender * Age group * Season & 12 & 1.771 & 0.047 & 0,002 \\
\hline
\end{tabular}

${ }^{*}$ General linear model-Univariate analysis, $\mathrm{R} 2=0.250$ 
Table 4. Comparison of vitamin $D$ levels by gender, age group, admission season and vitamin D status.

\begin{tabular}{llll}
\hline & & $\begin{array}{c}\text { Vitamin D Levels } \\
\text { (Mean } \pm \text { SD) }\end{array}$ & $\mathbf{P}^{*}$ \\
\hline Gender & Female & $15.8 \pm 10.1$ & $<0.001$ \\
Age group & Male & $19.4 \pm 10.3$ & \\
& $28 \mathrm{~d}-12 \mathrm{~m}$ & $27.3 \pm 16.6$ & \\
& $13 \mathrm{~m}-2 \mathrm{y}$ & $22.5 \pm 13.4$ & \\
& $2-5 \mathrm{y}$ & $18.9 \pm 9.3$ & $<0.001$ \\
Season & $6-11 \mathrm{y}$ & $17.2 \pm 8.3$ & \\
& $12-18 \mathrm{y}$ & $13.6 \pm 7.9$ & \\
& Winter & $13.1 \pm 8.9$ & \\
& Spring & $18 \pm 11$ & \\
& Summer & $21 \pm 10.4$ & \\
& Autumn & $19.1 \pm 9.4$ & \\
& ${ }^{*}$ Sidak adjusted multiple comparisons, SD: Standard deviation &
\end{tabular}

shown in Table 4.

The vitamin $D$ levels in the winter season were the lowest, and those in the summer season were the highest, yielding values of $13.1 \pm 8.9 \mathrm{ng} / \mathrm{mL}$ in the winter and $21 \pm 10.4 \mathrm{ng} / \mathrm{mL}$ in the summer $(P<$ 0.001). According to the multiple comparisons tests, the differences in vitamin $D$ levels between seasons were statistically significant $(P<0.001)$ (Table 4$)$. The vitamin $\mathrm{D}$ level of the patients in the deficiency group were $12 \pm 4.4 \mathrm{ng} / \mathrm{mL}$, while a value of $24.1 \pm$ $2.7 \mathrm{ng} / \mathrm{mL}$ was determined in the insufficiency group and a value of $39.7 \pm 11.3 \mathrm{ng} / \mathrm{mL}$ was determined in the sufficiency group. Vitamin $D$ levels by gender, age group, and season of admission are presented in Table 5.

\section{DISCUSSION}

This study is the first study in which the Vitamin D levels of children aged $0-18$ in the central Anatolian region were evaluated according to age groups, gender, and seasons. It differs from similar studies in the literature in terms of a large number of cases and the comparison of mean vitamin $D$ levels according

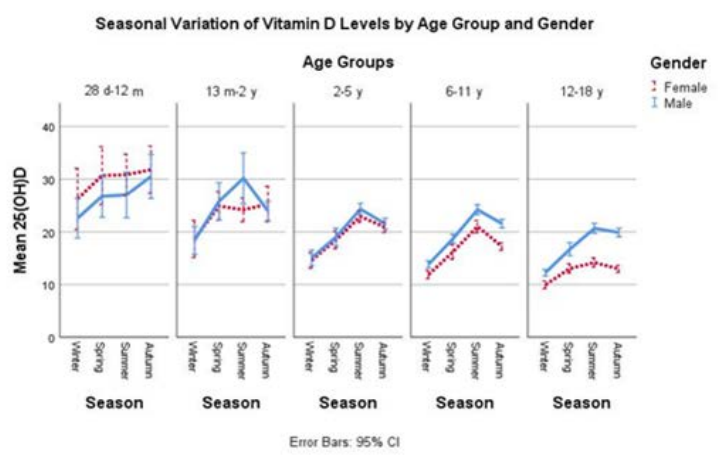

Figure 1. Seasonal variation of vitamin $D$ levels by age group and gender.

to vitamin D status (deficiency, deficiency, adequacy). In this regional study, we found that vitamin $D$ levels were lower than expected values and that these levels were significantly affected by age group, gender, and the season of admission.

Vitamin $D$ is a vitamin that has important functions in the human body and has been associated with many systems. Its functions are not limited to calcium and phosphate metabolism. Apart from its effects on the skeletal system, vitamin $D$ deficiency has been associated with obesity, asthma, Type 2 diabetes mellitus, cardiovascular diseases, neurological problems, and cancer $(2,4,10)$. It has been reported that vitamin $D$ is effective in the development and maintenance of the immune system, and the tendency to some infectious diseases increases in cases of vitamin D deficiency (11). Today, vitamin D deficiency/ insufficiency is accepted as global and important public health problems $(3,12)$. In fact, some recent studies consider vitamin $D$ deficiency as a worldwide pandemic (10). The Middle East, India, China, and Mongolia are regions where vitamin $D$ deficiency is widespread and most severe. The main risk groups are

Table 5. Vitamin D levels by gender, age group and admission season.

\begin{tabular}{|c|c|c|c|c|c|c|}
\hline & & \multicolumn{5}{|c|}{ Age group (Mean \pm SD) } \\
\hline & & $28 d-12 m$ & $13 m-2 y$ & $2-5 y$ & $6-11 y$ & $12-18 y$ \\
\hline \multirow[t]{2}{*}{ Winter } & Male & $21.6 \pm 15.2$ & $17.7 \pm 13.3$ & $14.1 \pm 7.6$ & $13.8 \pm 7.1$ & $12.2 \pm 5.7$ \\
\hline & Female & $24.2 \pm 17.6$ & $16.6 \pm 11.4$ & $14.1 \pm 10.1$ & $11.6 \pm 5.3$ & $9.6 \pm 6.8$ \\
\hline \multirow[t]{2}{*}{ Spring } & Male & $26.8 \pm 17.5$ & $24.7 \pm 15.1$ & $18.1 \pm 8.2$ & $18.7 \pm 7.5$ & $16.7 \pm 9$ \\
\hline & Female & $28.8 \pm 15.7$ & $24.9 \pm 15.1$ & $17.9 \pm 9.3$ & $15.4 \pm 8$ & $13.1 \pm 9.1$ \\
\hline \multirow[t]{2}{*}{ Summer } & Male & $27 \pm 16$ & $25.6 \pm 15.1$ & $24.3 \pm 8.5$ & $24.2 \pm 7.3$ & $20.7 \pm 7.3$ \\
\hline & Female & $30.9 \pm 15.8$ & $24.2 \pm 11.6$ & $22.9 \pm 8.4$ & $21.0 \pm 9.5$ & $13.7 \pm 7$ \\
\hline \multirow[t]{2}{*}{ Autumn } & Male & $30.5 \pm 17.3$ & $24 \pm 10.3$ & $21.3 \pm 7.7$ & $21.6 \pm 7.5$ & $19.9 \pm 6.7$ \\
\hline & Female & $31.8 \pm 15$ & $23.4 \pm 10.9$ & $20.9 \pm 8.3$ & $17.2 \pm 6.7$ & $12.8 \pm 6.5$ \\
\hline
\end{tabular}

SD: Standard deviation 
children, adolescents, pregnant women, the elderly, and immigrants. It is estimated that more than $50 \%$ of the world population do not have sufficient vitamin $D$ levels, especially in winter (13). There is not yet a prevalence study regarding vitamin $\mathrm{D}$ deficiency or insufficiency in children that covers the whole country of Turkey. However, there are studies conducted on a regional or provincial basis. The data obtained as a result of regional studies involving children over the last 10 years show that the western and southern regions of Turkey have higher vitamin $D$ levels than the eastern and northern regions. Doğan et al. (14) reported that the mean vitamin $D$ levels of the cases aged 1 month to 18 years in Izmir in 2015 were 28 $\mathrm{ng} / \mathrm{mL}$, and in 2016, Fettah et al. (15) demonstrated that the vitamin $D$ levels of the cases aged $0-18$ years in Erzurum were $17.1 \mathrm{ng} / \mathrm{mL}$. Durmaz et al. (16) reported a mean vitamin D level of $16.3 \mathrm{ng} / \mathrm{mL}$ in children aged 0-18 in Amasya in 2015, and Bucak et al. (17) reported a mean vitamin D level of $32.9 \mathrm{ng} / \mathrm{mL}$ in children aged 1 month to 10 years in Adıyaman in 2016.

There are some factors that affect the regional variation of vitamin $D$ levels in Turkey. The main influencing factor is the degree of exposure to sunlight. Seasonal and climatic conditions, altitude above sea level, geographical location, and social lifestyle (for example, the way of dressing) affect the exposure time of the skin to the sun. In terms of the geographical location of Turkey, the most suitable period of the year for vitamin $D$ synthesis is between May and November and between the hours of 10:00 to $15: 00$ during the day (18). Vitamin $D$ levels in the Central Anatolia region reflect the average of Turkey in terms of geographical location (18-22). Studies on the vitamin $D$ levels of children in the last 10 years in the Central Anatolia region included different age groups. Demiral et al. (19) reported the mean vitamin $D$ level as $11.9 \mathrm{ng} / \mathrm{mL}$ for cases aged 3-18 years in Ankara in 2016, and Solak et al. (18) found the mean vitamin $D$ levels to be $15.2 \pm 8.8 \mathrm{ng} / \mathrm{mL}(14.5 \pm 8.8$ $\mathrm{ng} / \mathrm{mL}$ in females, $18.1 \pm 8.4$ in males) for participants aged 0-18 years in their study that included adults in 2018. In this study, the mean vitamin $D$ levels were found to be $15.8 \pm 10.1 \mathrm{ng} / \mathrm{mL}$ in girls and $19.4 \pm 10.3$ $\mathrm{ng} / \mathrm{mL}$ in boys, and these results are consistent with the literature.

Studies on Vitamin D levels in children in Turkey are not homogeneous in terms of demographic characteristics and study methodologies. Although the units of measurement for vitamin $D(\mathrm{ng} / \mathrm{mL})$ are the same in the studies, the reference intervals for the diagnosis of vitamin $D$ deficiency or insufficiency are different. In addition, many of the studies include different and partial age ranges between the ages of 0-18 or included adults. Methodologically, the closest study to our study is the study by Topal et al. (7) in 2016, in which the vitamin D levels of children aged 0-18 in Erzincan were evaluated according to age, gender, and seasonal characteristics. The mean vitamin D levels obtained by Topal et al. (7) were 21.3 $\pm 14.9 \mathrm{ng} / \mathrm{mL}$ in girls and $22.5 \pm 13.9 \mathrm{ng} / \mathrm{mL}$ in boys. These results are higher than the values we obtained, and the gender difference is less than found in our study. In both studies, the highest vitamin D levels belonged to children aged 0-12 months, vitamin $D$ levels decreased with age, and the lowest vitamin D levels belonged to children aged 12-18 years. In both this study and the study conducted by Topal et al. (7), the lowest vitamin D levels were observed in the winter months, and the highest values are observed in the summer months. Although Topal et al. (7) reported that there was no difference between winter and spring in terms of mean vitamin D levels, in our study, vitamin $\mathrm{D}$ levels determined in spring were significantly higher than those determined in winter. The probable reason for this is that the number of sunny days in spring is higher in the Central Anatolia region than in the Eastern Anatolia region.

In our study, in addition to previous studies, we also evaluated mean vitamin $D$ levels according to vitamin $D$ status (deficiency, insufficiency, sufficiency). We think that this is important in terms of revealing the severity of vitamin $D$ deficiency and insufficiency. According to our results, the mean vitamin $D$ levels were $12 \pm 4.4 \mathrm{ng} / \mathrm{mL}$ in the deficiency group, 24.1 $\pm 2.7 \mathrm{ng} / \mathrm{mL}$ in the insufficiency group, and $39.7 \pm$ $11.3 \mathrm{ng} / \mathrm{mL}$ in the sufficiency group. We think that these results will serve as a reference for studies with similar methodologies. Topal et al. (7) reported that apart from the main effects of age, gender, and season, only the interaction between age and season affected vitamin $D$ levels. According to the general linear model procedure we used in our study, it was determined that the main effects of age group, gender and application season, as well as, the interactions of these three factors were significantly effective on vitamin D levels.

When all age groups are taken into account, vitamin $D$ levels are at the level of deficiency in children under the age of two and deficiency was detected in children between the ages of 2-18. The key limitation of this 
study is that it is a retrospective archive study. This study includes children who applied to the hospital and whose vitamin D levels were determined after the evaluation. It does not include the symptoms, physical examination findings and related laboratory findings suggesting vitamin $D$ deficiency in the participants. Despite the large number of participants, the fact that vitamin $D$ deficiency/insufficiency is so evident raises the questions about the vitamin $D$ levels in healthy children. Prevalence studies on vitamin D deficiency/ insufficiency in asymptomatic and healthy children may provide reference ranges determined according to age groups.

As in the whole world, vitamin D levels in children were found to be lower than expected in this regional study. Vitamin D levels in children aged 0-18 have significant variability according to gender, age group, and seasons. In order to prevent health problems that may develop due to vitamin $D$ deficiency or insufficiency, public awareness should be raised about a balanced diet, benefiting from sunlight in a healthy way. Further, public health practices that support nutrition in terms of vitamin $D$ should be planned, and these interventions should all be developed according to age, gender, and seasonal conditions. We think that future studies should follow a similar methodology to the one used in this study in order to reveal the prevalence of vitamin D deficiency/ insufficiency in children and to make temporal and regional comparisons across different age groups.

Conflict of interest: Authors declare that there is no conflict of interest between the authors of the article.

Financial conflict of interest: Authors declare that they did not receive any financial support in this study.

Address correspondence to: Zafer Bagci, University of Health Sciences, Konya City Hospital, Department of Pediatrics, Konya, Turkey.

e-mail: zfrbagci@gmail.com

\section{REFERENCES}

1. Kulie T, Groff A, Redmer J, et al. Vitamin D: An evidencebased review. J Am Board Fam Med 2009;22(6):698-706.

2. Holick MF, Binkley NC, Bischoff Ferrari HA, et al. Evaluation, treatment, and prevention of vitamin D deficiency: An Endocrine Society clinical practice guideline. J Clin Endocrinol Metab 2011;96(7):1911-30.

3. Holick MF, Chen TC. Vitamin D deficiency: A worldwide problem with health consequences. Am J Clin Nutr 2008;87(4):1080S-6S.

4. Pludowski P, Holick MF, Pilz S, et al. Vitamin D effects on musculoskeletal health, immunity, autoimmunity, cardiovascular disease, cancer, fertility, pregnancy, dementia and mortality-a review of recent evidence. Autoimmunity reviews 2013;12(10):976-89.

5. Arabi A, El Rassi R, and Fuleihan GEH. Hypovitaminosis D in developing countries-prevalence, risk factors and outcomes. Nature Reviews Endocrinology 2010;6(10):550-61.

6. Williams K, Thomson D, Seto I, et al. Standard 6: Age groups for pediatric trials. Pediatrics 2012;129(Supplement 3):S15360.

7. Topal İ, Mertoğlu C, Arslan YK, et al. Erzincan bölgesindeki çocukların D vitamini seviyelerinin yaş, cinsiyet ve mevsimlere göre değerlendirilmesi. Fırat Tıp Dergisi 2018;23(4):168-72.

8. Taylor PN, Davies JS. A review of the growing risk of vitamin $\mathrm{D}$ toxicity from inappropriate practice. $\mathrm{Br} \mathrm{J}$ Clin Pharmacol 2018;84(6):1121-7.

9. Balasubramanian S, Dhanalakshmi K, and Amperayani SJlp. Vitamin D deficiency in childhood-A review of current guidelines on diagnosis and management 2013;50(7):66975.

10. Holick MF. The vitamin D deficiency pandemic: Approaches for diagnosis, treatment and prevention. Rev Endocr Metab Disord 2017;18(2):153-65.

11. Laaksi I, Ruohola JP, Tuohimaa P, et al. An association of serum vitamin $D$ concentrations $<40 \mathrm{nmol} / \mathrm{L}$ with acute respiratory tract infection in young Finnish men. Am J Clin Nutr 2007;86(3):714-7.

12. Pettifor JM, Thandrayen K, Thacher TD. Vitamin D. In: Feldman D, ed. Vitamin D deficiency and nutritional rickets in children. Amsterdam: Elsevier 2018:179-201.

13. van Schoor N, Lips P. Vitamin D. In: Feldman D, ed. Worldwide vitamin D status. London: Academic Press 2018:15-40.

14. Doğan N, Colak A, Güden N, et al. Vitamin D deficiency in children in Aegean region in Turkey. Cumhuriyet Medical Journal 2015;37(1):17-22.

15. Fettah A, Reis G, Erten I, et al. The effect of serum vitamin D levels on anemia and iron parameters in children and review of the literature. Medicine Science | International Medical Journal 2016;5(3):821-5.

16. Durmaz Z, Demir A, Tiryaki $M$, et al, Amasya bölgesinde hastaneye başvuran bireylerde vitamin $D$ düzeyleri. Bozok Tıp Dergisi 2015;5(3):26-32.

17. Bucak $\mathrm{iH}$, Almış $\mathrm{H}$, The retrospective analysis of vitamin $\mathrm{D}$ levels of pediatric patients in a small city center in Turkey. Sakarya Tıp Dergisi 2016;6(3):136-40.

18. Solak I, Cihan FG, Mercan S, et al. Evaluation of 25-hydroxyvitamin D levels in central anatolia, Turkey. Biomed Res Int 2018;2018:4076548.

19. Demiral M, Sırmagül B, and Kirel B. Endokrin polikliniğine başvuran çocuklarda D vitamini düzeyleri. Güncel Pediatri 2016;14(2):60-6.

20. Öğüş $E$, Sürer $H$, Kılınç $A S ̧$, et al. D vitamini düzeylerinin aylara, cinsiyete ve yaşa göre değerlendirilmesi. Ankara Medical Journal 2015;15(1):1-5.

21. Andıran N, Celik N, Akca H, et al. Vitamin D deficiency in children and adolescents. J Clin Res Pediatr Endocrinol 2012;4(1):25.

22. Oden Akman A, Tumer L, Hasanoglu A, et al. Frequency of vitamin $D$ insufficiency in healthy children between 1 and 16 years of age in Turkey. Pediatrics International 2011;53(6):968-73. 